\title{
The Effect of Customer Relationship Management to Speedy/Indihome Customer Loyalty And Strategic Implementation In Telkom E-Service
}

\author{
Taufan Umbara \\ Study Program Master of Management, Postgraduate \\ Faculty, Telkom University \\ Bandung, Indonesia \\ taufanu@gmail.com
}

\author{
Maya Ariyanti \\ Study Program Master of Management, Postgraduate \\ Faculty, Telkom University \\ Bandung, Indonesia \\ maya.ariyanti@gmail.com
}

\begin{abstract}
Based on the results of a survey conducted by the Association of Indonesian Internet Service Provider (Penyelenggara Jasa Internet Indonesia/APJII), it was discovered that the internet subscribers in Indonesia in 2014 grew by $30.49 \%$. There was a paradox if we compare the growth of Speedy/Indihome Telkom subscribers to the internet user growth in Indonesia. Telkom was supposed to be able to totally use the internet users by increasing the number of Speedy Telkom subscribers. In fact, the growth number of Speedy subscribers was only $0.4 \%$ and, in general, it was considered much lower than the growth number of internet users in Indonesia.

The purpose of this research was to reveal the influence of Customer Relationship Management (CRM) on the loyalty of the Speedy/Indihome subscribers. In accordance with the research purpose, the research used the study of causality, and the nature of this research was verification. From the questionnaire distributed, 182 valid questionnaires were gained. The method of data analysis used path analysis.

From the research findings, it can be concluded that the independent variables, namely Competence, Relationship, Caring, and Thrust significantly and positively affected the loyalty, meanwhile Sharing Information did not. The effect of those variables on Loyalty was $81.2 \%$ and the highest was Competence with $38.2 \%$.

The highest variable influencing the subscribers' loyalty was Competence. Telkom has to focus more on the effort of improving the staff competencies, especially dealing with the Speedy/Indihome subscribers in order to maintain their loyalty. With this high subscribers' loyalty, the company is easier to increase the values of each subscriber in order to improve the company's income.
\end{abstract}

Keywords: subscribers loyalty, competence, CRM, Speedy/Indihome, path analysis.

\section{INTRODUCTION}

Telkom is telecommunication service company. As a service company, Telkom has to give the best service for its customers, supposing they always use Telkom products. Along with technology development and government policy to open competition era in telecommunication, the challenge for Telkom to always give the best service for customers becomes more challenging and complex. Therefore Telkom has to consider the best way to make its customer bounded with Telkom, which is not easy. All this time Telkom was too arrogant by assuming that customers need Telkom, this is probably due to the fact that Telkom has long been monopolizing telecommunication business. Telkom did not realize that customers can freely choose which operator they want to use.

Today, one of Telkom best products is Speedy. Speedy is Telkom product that provides subscription for internet access service in high speed (broadband access), which uses Asymmetric Digital Subscriber Line (ADSL) technology. It has upstream access ability up to $64 \mathrm{Kbps}$ and downstream service up to $1024 \mathrm{Kbps}$. It also provides telephony conversation simultaneously, and was well known by customers in 2000s. On January 2015 speedy brand had no longer been used and was transformed into Indihome. It provides the following services such as Internet on Fiber or High Speed Internet, Phone (home telephony), and IPTV (UseeTV Cable), with some additional features such as IndiHome View, MelOn, and Trend Micro Security System.

In order to give best service, Telkom opens some service canals such as walk-in by Plasa Telkom and phone-in by Call 147. Telkom attempts to increase the service in Plasa Telkom by designing comfortable waiting room and kind service. Likewise, by using line 147 Telkom tries to upgrade the number of customer services in order to reduce the time of queue and provides personality training intended for the customer services so that they could be empathetic to the customers.

Plasa Telkom and 147 service seem to have started to be abandoned by Telkom customers who are internet minded; they have no time to visit Plasa Telkom just to share their problem. They were also tired to call 147, because most of the time, it went to entry calling queue, and although they were serviced, they were not given certainty regarding the repair time. As a result, this type of customers let the 
telephony or speedy not work and they alter tousing other operator that better fulfills their communication need. This can be evidenced through the amount of customer "apparent death" growth reaching $12,83 \%$ in January - December 2014 , whereas the amount of speedy "new customers" growth is only $0,4 \%$.

On the contrary, based on survey conducted by Asosiasi Penyelenggara Jasa Internet Indonesia (APJII) cooperated with Pusat Kajian Komunikasi (Puskakom) FISIP Universitas Indonesia, the number of internet users in Indonesia 2014 has grown 22,4\% (see Figure 1), or it becomes paradox if we compare the growth of Speedy customer and internet users in Indonesia. Telkom can necessarily maximize toutilize the growth of internet users.

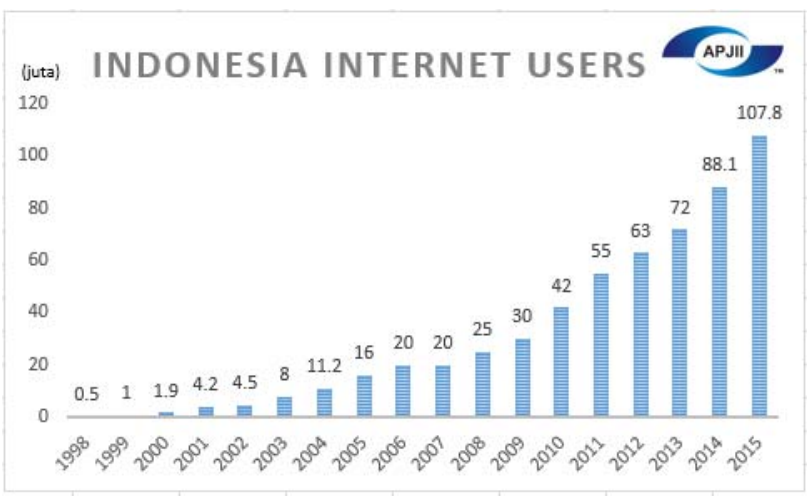

Figure 1. The Growth of Internet Users in Indonesia

From Table 1, there are many customers using web-in channel to deliver their complaint, and if we look into Divre II Jakarta, it has the most customers using this media. It means the mobility level of customer in Jakarta is high, therefore web-in becomes the best choice for them.

\section{TABle 1. TELKom Customer COMPLAint DATA}

\begin{tabular}{|c|c|c|c|c|c|}
\hline \multirow{2}{*}{ No. } & \multirow{2}{*}{ DIVISI/ CENTER } & \multicolumn{3}{|c|}{ Jumlah e-mail } & \multirow{2}{*}{$\begin{array}{r}\text { Persentase } \\
\text { Closed }\end{array}$} \\
\hline & & OPEN & CLOSED & TOTAL & \\
\hline 1. & DIVRE I & 0 & 674 & 673 & $100 \%$ \\
\hline 2. & DIVRE II & 0 & 2.918 & 2.918 & $100 \%$ \\
\hline 3. & DIVRE III & 0 & 3031 & 803 & $100 \%$ \\
\hline 4. & DIVRE IV & 0 & 677 & 677 & $100 \%$ \\
\hline 5. & DIVRE V & 34 & 683 & 717 & $95.26 \%$ \\
\hline 6. & DIVRE VI & 0 & 348 & 348 & $100 \%$ \\
\hline 7. & DIVRE VII & 4 & 628 & 632 & $99.37 \%$ \\
\hline 8. & DTF & 111 & 456 & 567 & $79.17 \%$ \\
\hline 8. & UNIT LAIN & 64 & 2.933 & 2.991 & $98.06 \%$ \\
\hline & TAL Web-In & 214 & 10.120 & 10.319 & $98.07 \%$ \\
\hline
\end{tabular}

The table illustrates the implication ofthe internet minded customers who do not get their expected service from Telkom. They usually shed all of their regret through social media. Telkom should anticipate technology development to upgrade its customer service. If Telkom did not immediately adapt to their customer service, it is not possible to be better, and therefore more customers are frustrated and eventually leave Telkom without advance permission. Telkom does not realize that they are being left.

The research purpose for this paper is as follow:
- Explain the study result regarding Speedy/Indihome CRM and customer loyalty.

- Explain the level of CRM effect towards Speedy/Indihome customer loyalty in partial and simultaneous.

- Explain the study result of Telkom e-service strategic implementation as CRM Tools.

\section{LitERATURE REVIEW AND RESEARCH SCOPE}

\section{A. Marketing and Value Creation}

Based on American Marketing Association in Kotler and Keller [1], Marketing is an organization function and a set processes for creating communication, delivering value to customers, and for managing customer relationship in ways that benefit the organization and its stakeholders. Marketing is organizational function and a series processes to create, communicate, and give value to customer to manage customer relationship by profitable way for organization and stakeholder.

The business target is to deliver customer value that generates profit. To create and deliver value consists of value choosing phase, value providing phase, and value communicating phase. The success of organization to realize the goal is determined by organization ability in identifying need and want of the target market effectively and efficiently compared to its competitors [2].

\section{B. Customer Satisfaction}

The word 'satisfaction' comes from Latin language "satis" (it means good enough, adequate) and "facio" (do or create). Satisfaction can be interpreted as "effort to comply something" or "make something adequate". However, it can be reviewed in customer behavior perspective, that the term "customer satisfaction" becomes a complex issue. Customer satisfaction has become central concept in marketing theory and practice, also one of the essential things for business activity. Customer satisfaction contributes to some crucial aspects, such as customer loyalty creation, company reputation, decrease of price elasticity, decrease of future transaction, increase of employee efficiency and effectiveness. Besides that, customer satisfaction can be also regarded as one of the best indicators to grasp future profit [3]. The facts that attracting new customers are more expensive than maintaining the existing customer can be one of the triggers to increase the attention to customer satisfaction.

\section{Customer Retention}

The main goal of each business is to create and maintain customers. Unfortunately there are many companies (including Telkom) that focus more on new customers rather than on customer retention that has existed. Based on Clancy \& Shulman research [4], this focus is very wrong because it is just a short-term oriented and it is called "Death Wish Paradox". Their research results of some product categories show that maintaining cost of customer is only $25 \%$ from getting new customers.

Positive word-of-mouth, based on customer stair-loyalty that satisfies and is loyal for company services or products company are priceless and therefore can be assumed as the "representative" company that has potential to spread positive experiences to others [5]. Additionally, loyal 
customers also have potential to buy other products, so company income can increase. However, maintaining customer is not an easy task. The high customer satisfaction score or rank cannot guarantee that the company can maintain customers forever. The research indicates that $65 \%$ - $85 \%$ of the customers will move to competitors are those who "satisfy" or "very satisfy" with previous service provider.

\section{Customer Relationship Management}

The development of information communication and technology that can provide easiness in information fast access will contribute more on smart and sophisticated customers in millennium era. Present customers become more difficult to be satisfied. They need customized product, speed, flexibility, quality, superior service, and cost effective solutions. Therefore, the company will not survive without the ability to understand its customer and providing products and services that are more customized. CRM is customer identification process, customer knowledge creation, customer relationships development, and it creates customer perception to organization and their solutions. CRM is process to obtain, maintain, and develop profitable customers. CRM needs clear focus or value added service attributes for their customers and needs to create customer loyalty. CRM consists of 5 (five) main elements such as strategy, segmentation, technology, process, and organization. CRM is a process to create and manage relationship with customer on organization level by understanding, anticipating, and managing customer needs, in terms of increasing effectiveness, efficiency, and organizational profitability. CRM implementation promises mount of benefits, such as cost effectiveness, customer satisfaction and customer loyalty, profitability, word of mouth communication, and business partnership synergy. The benefit is usually reached by some of core measurements; Life-Time Value (LTV), Average Order Value (AOV), Retention, Frequency, Monetary analysis (RFM), Share of Customer Spending, Rate of Customer Recovery, and Referral Revenue. Word of mouth can be implemented fast by e-mail, newsgroups, chatting, and personal web page. Meanwhile business partnership synergy can be implemented by business cooperation collaborating commitment and sharing information, skill, and knowledge.

\section{E. Path Analysis}

Path analysis was started in 1920 s by Sewall Wright; a genetic engineering. Path analysis technique is correlation development that is said to become the effect that is raised, path analysis has similarity with multiple regression. In other way, multiple regressions are special shape from path analysis. This technique is as well known as causing model. It is based on path analysis that proposition theory can be tested concerning the causing model without variables manipulation.

Path analysis model is used to analyze correlation pattern among variables in which the purpose of a set of independent variable to dependent variable is directly or indirectly known. . Therefore, the problem definitions are:

1. Does independent variable $(X 1, X 2, \ldots, X k)$ have effect to dependent variable (Y)?

2. How big is the effect of directly causing,
3. Indirectly causing, total causing or simultaneous independent variable $(\mathrm{X} 1, \mathrm{X} 2, \ldots, \mathrm{Xk})$ to dependent variable?

\section{F. S.W.O.T. Analysis}

SWOT analysis is important strategic tools to help planner to compare the strength and weakness of internal organizations that have opportunity and external threat. SWOT analysis needs to be implemented because it can comply internal resource and external condition. SWOT analysis can maximize strength and opportunity, at the same time itminimizes weakness and threat.

\section{RESEARCH METHODOLOGY}

\section{A. Research Type}

The type of this research is verification, and is used to test the truth of a hypothesis. The goal of this research is to discover causal relationship that will explain an effect of a variable/s onto other variable/s directly or not. In other words, the use of this method is to see how big the role and effect of a variable that will be shown by path coefficient.

\section{B. Operational Variable}

\section{1) Independent Variable}

Sugiyono [6] states that the meaning Independent variable is variable that causes or become the raise of dependent variable. The independent variable in this research is Customer Relationship Management (CRM) (X).

\section{2) Dependent variable}

In addition to that, Sugiyono [6] states that dependent variable is variable that is caused by or become impacted. Dependent variable in this research is customer loyalty $(\mathrm{Y})$.

\section{Quantitative Method}

In the quantitative method, the problems that are studied are more general in scope, complex variants of level. Quantitative method is more systematic, such as structural, clear from beginning until the end of the research. However the problems of qualitative method appoints to small scope with low variant level. From that research, we can develop the variant widely following the field report. Qualitative approach is research process and is an understanding of methodology that has social phenomena and human problem. In this approach, research procedures produce descriptive data such as written words or oral from people who are studied.

Descriptive statistical is statistical method which is more informative to be organized, summarized, and presented on the data. In this research, descriptive statistical is used to explain the characteristics of respondent and to describe research variable.

The description of research variables that are using frequency distribution table and analyze linear-continuum are:

1. Maximum index score is the result of the highest multiple score with the number of question item and the number of respondent.

2. Minimum index score is the result of the lowest multiple score with the number of question item and 
the number of respondent.

3. Percentage is total score divided by maximum index score multiple by 100 percent.

4. Interval range is maximum index score reduced by minimum index score and divided by 5 .

\section{Population and Sample}

Population is all of psychological objects that are limited by specific criteria. The psychological object can be concrete (for example person) or abstract (for example attitude). Based on Sugiyono [6], "Population is general areas that consist of object or subject which has quality and characteristic stated by researcher to be learned and then be drawn for the conclusion". Based on Jonathan Sarwono [7] "Population is defined as a complex analysis tools that are studied. The population of this research is Speedy/Indihome customer in Jakarta.

Sampling method that is used in this research is a nonprobability sampling. "Where not every individual in population is given the same right to become a sampling member. The Sampling method is purposive sampling. "Purposive sampling is a sample gathering technique following certain consideration, where the sample is chosen by the essential and relevant requirement with the research" [6]. Determining the sampling size of the population, based on amount of minimum sampling that is required by analytic tool. The cause of analytic method is used to analyze the path. Thus, ideal and representative sample are 100-200. This depends on the amount of parameter that can be estimated. The guidance is 5-10 times of parameter that can be estimated. The amount of sample is 5-10 multiple by indicator [8].

In this research, the question type is Close-Ended Question, whereas the question formats are multiple choice. All question are about Speedy customer services in Jakarta. Before the questionnaires were given, we performed pretesting, test of questionnaire to respondent with small sample, the goal is to improve the questionnaire by identifying and eliminating the problem [9]. Usually the pretest is given to 15 until 30 respondents. Based on statistical theory, pre-elimination research was conducted for 32 respondents face-to-face (respondent data can be seen on Table 2).

TABLE 2. PRETEST RESPONDENT DATA

\begin{tabular}{|c|c|c|c|c|}
\hline No & Variable & Category & Amount & Percentage \\
\hline \multirow[t]{2}{*}{1.} & \multirow[t]{2}{*}{ Gender } & Male & 20 & $62.50 \%$ \\
\hline & & Female & 12 & $37.50 \%$ \\
\hline \multirow[t]{5}{*}{2.} & \multirow[t]{5}{*}{ Age } & Less than 20 & 1 & $3.13 \%$ \\
\hline & & $21-30$ & 10 & $31.25 \%$ \\
\hline & & $31-40$ & 12 & $37.50 \%$ \\
\hline & & $41-50$ & 6 & $18.75 \%$ \\
\hline & & More than 50 & 3 & $9.38 \%$ \\
\hline \multirow[t]{5}{*}{3.} & \multirow{5}{*}{$\begin{array}{l}\text { Formal } \\
\text { Education }\end{array}$} & High School & 9 & $28.13 \%$ \\
\hline & & Diploma & 5 & $15.63 \%$ \\
\hline & & Graduate & 15 & $46.88 \%$ \\
\hline & & Postgraduate & 3 & $9.38 \%$ \\
\hline & & Doctoral & 0 & 0 \\
\hline \multirow[t]{2}{*}{4.} & \multirow[t]{2}{*}{ Job } & Student & 1 & $3.13 \%$ \\
\hline & & $\begin{array}{l}\text { Government } \\
\text { officer }\end{array}$ & 1 & $3.13 \%$ \\
\hline
\end{tabular}

\begin{tabular}{|c|c|c|c|c|}
\hline No & Variable & Category & Amount & Percentage \\
\hline & & Private & 21 & $65.63 \%$ \\
\hline & & Entrepreneur & 8 & $25 \%$ \\
\hline & & Army / police & 0 & 0 \\
\hline & & Others & 1 & $3.13 \%$ \\
\hline \multirow[t]{4}{*}{5.} & \multirow[t]{4}{*}{$\begin{array}{l}\text { Monthly } \\
\text { wages }\end{array}$} & $\begin{array}{l}\text { Less than IDR } 5 \\
\text { million }\end{array}$ & 18 & $56.25 \%$ \\
\hline & & IDR $5-10$ million & 5 & $15.63 \%$ \\
\hline & & IDR 10 - 20 million & 4 & $12.50 \%$ \\
\hline & & $\begin{array}{l}\text { More than IDR } 20 \\
\text { million }\end{array}$ & 5 & $15.63 \%$ \\
\hline \multirow[t]{4}{*}{6.} & \multirow[t]{4}{*}{$\begin{array}{l}\text { Subscriber } \\
\text { Period }\end{array}$} & $\begin{array}{lll}\begin{array}{l}\text { Less } \\
\text { months }\end{array} & \text { than } & 3 \\
\end{array}$ & 8 & $25 \%$ \\
\hline & & $6-12$ moths & 8 & $25 \%$ \\
\hline & & $1-3$ year(s) & 8 & $25 \%$ \\
\hline & & More than 3 years & 8 & $25 \%$ \\
\hline
\end{tabular}

\section{E. Validity and Reliability}

Validity and reliability are important aspects that have to be accounted in questionnaire arrangement to describe phenomenon measurement and trusted fact. This shall last until this research is accountable scientifically. If there is any similarity between collected data and real data in researching object, the result of reliable research may have similarity with time data in different period [6].

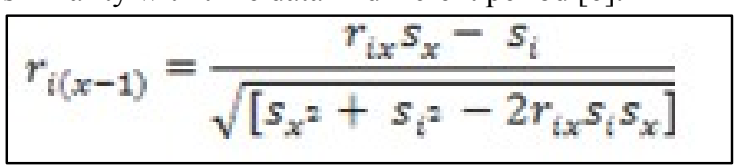

The validity test used is total-item correlation coefficient that has been corrected. Based on Kaplan and Saccuzo [10] "A question item is said valid and can measure research variable, if the validity coefficient is more than or similar with 0.361 ". To test the research instrument validity that has score in ordinal, the formula that is used can be seen in (1) Total-item Correlation Coefficient Formula.

Reliability is accuracy degree, precision, or fidelity that is shown by measurement instrument [11]. On the other hand, Sugiyono [6] mentions that reliable instrument is whenever the instruments used in some measurement object would produce same score. The high or low of empirical reliability is shown by score as known as reliability coefficient score. High reliability is shown by 1,00 , adequate reliability is more than 0,700 . The technique used by the writer to count the reliability is SPSS with AlphaCronbach coefficient. The formula that is used can be shown in (2).

$$
r_{11}=\left[\frac{n}{n-1}\right]\left[1-\frac{\sum \sigma_{t}^{2}}{\sigma^{2}{ }_{t}}\right]
$$

Equation 2. Alpha Cronbach Reliability Formula Measurement instrument tool can be said reliable and can be processed on the next stage if Alpha Cronbach score is more than 0,7 . If the reliability score is less than 0,7 , the measurement tool is not reliable [12]. 


\section{F. Data Analysis Technique}

Statistical study says that in relationship analysis that can predict $\mathrm{Y}$ score by $\mathrm{X}_{1}, \mathrm{X}_{2}, \ldots, \mathrm{X}_{\mathrm{p}}$ score, the suitable pattern is the relation pattern that follows regression model, yetfor cause and effect relationship, path analytic is used

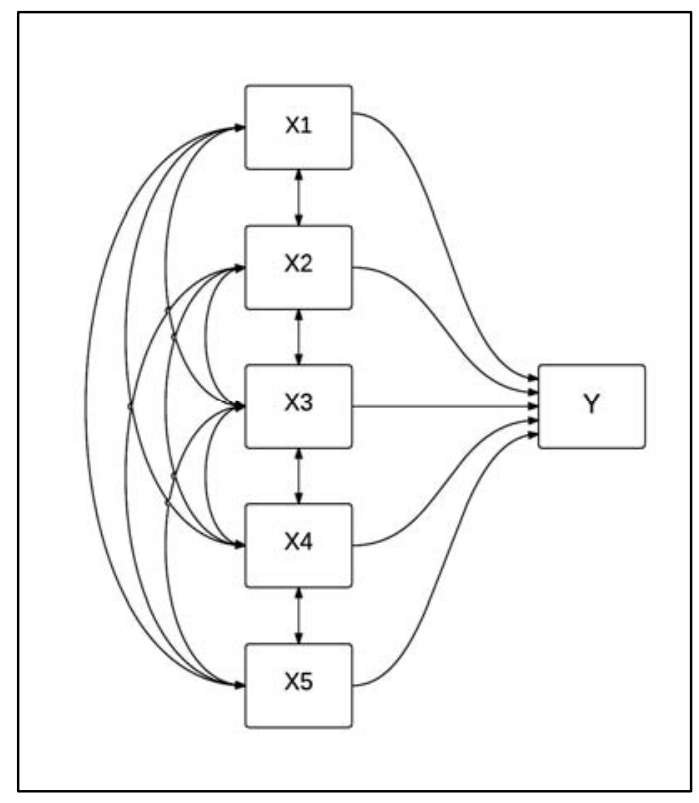

Figure 2. Research Mathematics Model

The question now is relationship pattern that can be described, it is the relationship that can be used to predict or foresee the $\mathrm{Y}$ respond-variable by the name of certain scores in predictor variable $\mathrm{X}_{1}, \mathrm{X}_{2}, \ldots, \mathrm{X}_{\mathrm{p}}$. Other than that relationship the relationship pattern that require how big the impact of $\mathrm{X}_{1}, \mathrm{X}_{2}, \ldots, \mathrm{X}_{\mathrm{p}}$ to $\mathrm{Y}$ variable requires not only independent one with direct impact but also togetherness.

Basically path analysis is structural linear regression analysis for standardized variables in closed system that is formally completed. Therefore, path analysis can be seen as structural analysis that examines causal relationship between variables in closed system. On Figure 2, we can see that we use one line equity model, it is independent variable consisting of $\mathrm{X} 1, \mathrm{X} 2, \mathrm{X} 3, \mathrm{X} 4$, and $\mathrm{X} 5$ with $\mathrm{Y}$ as the dependent variable.

\section{RESEARCH RESULT}

\section{A. Respondent Characteristics}

Respondents in this research are obtained through questionnaire spreading in Plasa Telkom Jakarta and are operated by Telkom Customer Care officer. The total number of the respondents is 225 persons.

The 43 respondents eliminated in screening question are those who are not Speedy/Indihome customers. Therefore, validated customers are 182 persons $(80.88 \%)$.

\section{B. Respondent Responses on Competence (X1)}

Ideally, the expected score from 9 questions is 11.466. Based on calculation, we get 9186 or $80,1 \%$ from ideal score 11.466 . Therefore, the competence (X1) is very good.

\section{Respondent Responses About Relationship (X2)}

Ideally, the expected score from 5 questions is 6.370 . Based on calculation, we get 4.669 or $73,3 \%$ from ideal score 6.370. It indicates that Relationship (X2) is good.

\section{Respondent Responses About Caring (X3)}

Ideally, the expected score from 3 questions is 3.822 . Based on calculation, we get 2.698 or $70,6 \%$ from ideal score 3.822. It can be said that Caring (X3) is good.

\section{E. Respondent Responses About Trust (X4)}

Ideally, the expected score from 2 questions is 2.548 . Based on calculation, we get 1.716 or $67,3 \%$ from ideal score 2.548. Thus, Trust (X4) is good.

\section{F. Respondent Responses About Sharing Information (X5)}

Ideally, the expected score from 2 questions is 2.548 . Based on calculation, we get 1.801 or $70,7 \%$ from ideal score 2.548. It can be acknowledged that Sharing information (X5) is good.

\section{G. Customer Relationship Management (X) Descriptive Calculation}

Ideally, the expected score from CRM is 26.754. Based on calculation, we get 20.070 or $75,01 \%$ from ideal score 26.754. It can be concluded that CRM (X) is good.

\section{H. Loyalty Description ( $Y$ )}

Ideally, the expected score from 9 questions is 7.644. Based on calculation, we get 5.786 or $70,1 \%$ from ideal score 7.644. Therefore, Loyalty (Y) is good.

I. The effect of Competence (X1), Relationship (X2), Caring (X3), Trust (X4), and Sharing Information (X5) to Loyalty $(Y)$

Hypothesis test is conducted to examine how big the effect of Competence (X1), Relationship (X2), Caring (X3), Trust (X4), and Sharing Information (X5) to Loyalty (Y).

TABle 3. Correlation Matrix Between VARIABLES

\begin{tabular}{|c|c|c|c|c|c|c|}
\hline $\begin{array}{c}\text { Vari } \\
\text { able }\end{array}$ & $\mathrm{X} 1$ & $\mathrm{X} 2$ & $\mathrm{X} 3$ & $\mathrm{X} 4$ & $\mathrm{X} 5$ & $\mathrm{Y}$ \\
\hline $\mathrm{X} 1$ & 1 & 0,761 & 0,588 & 0,566 & 0,672 & 0,832 \\
\hline $\mathrm{X} 2$ & 0,761 & 1 & 0,795 & 0,739 & 0,591 & 0,825 \\
\hline $\mathrm{X} 3$ & 0,588 & 0,795 & 1 & 0,727 & 0,519 & 0,722 \\
\hline $\mathrm{X} 4$ & 0,566 & 0,739 & 0,727 & 1 & 0,465 & 0,719 \\
\hline $\mathrm{X} 5$ & 0,672 & 0,591 & 0,519 & 0,465 & 1 & 0,638 \\
\hline $\mathrm{Y}$ & 0,832 & 0,825 & 0,722 & 0,719 & 0,638 & 1 \\
\hline
\end{tabular}

In path analysis method, to discover causal relationship or effect of research variables, firstly we have to calculate correlation matrix from Competence (X1), Relationship (X2), Caring (X3), Trust (X4), and Sharing Information (X5) to loyalty (Y). The correlation matrix between variables can be seen in Table 3 . 


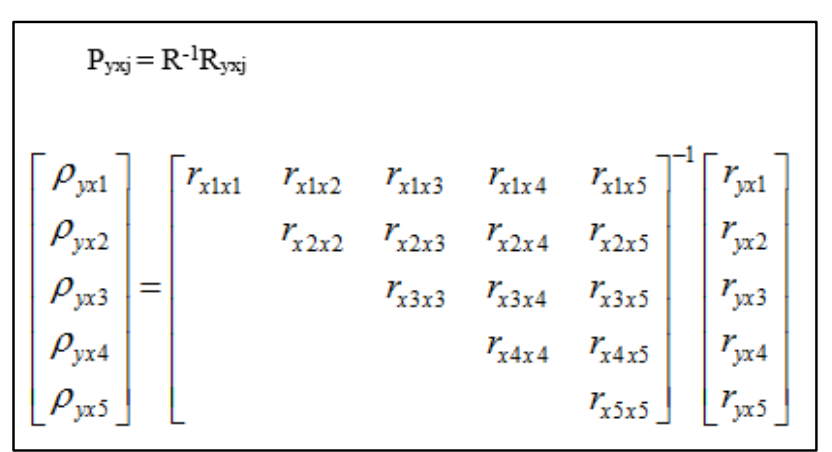

Figure 3. Path Coefficient Equity

Based on the calculation result from correlation and inverse matrix, we can get path coefficient, the total effect from X1, X2, X3, X4, X5 and other variable path coefficient outside X1, X2, X3, X4 and X5 (residue coefficient). therefore, path coefficient can be seen in table 4 .

TABle 4. PATH COEFFicient

\begin{tabular}{|c|c|c|c|}
\hline Variable & Path Coefficient & Simultaneously Effect & $\begin{array}{c}\text { Residual } \\
\text { Effect }\end{array}$ \\
\hline Competence (X1) & Pyx1 $=0.459$ & \multirow{5}{*}{0,812} & \multirow{5}{*}{0,188} \\
\hline Relationship (X2) & Pyx $2=0.200$ & & \\
\hline Caring (X3) & Pyx3 $=0.120$ & & \\
\hline Trust (X4) & Pyx4 $=0.198$ & & \\
\hline $\begin{array}{l}\text { Sharing Information } \\
\text { (X5) }\end{array}$ & Pyx5 $=0.157$ & & \\
\hline
\end{tabular}

Figure 4 shows the effect of Competence (X1), Relationship (X2), Caring (X3), Trust (X4), and Sharing Information (X5) path diagram to loyalty (Y).

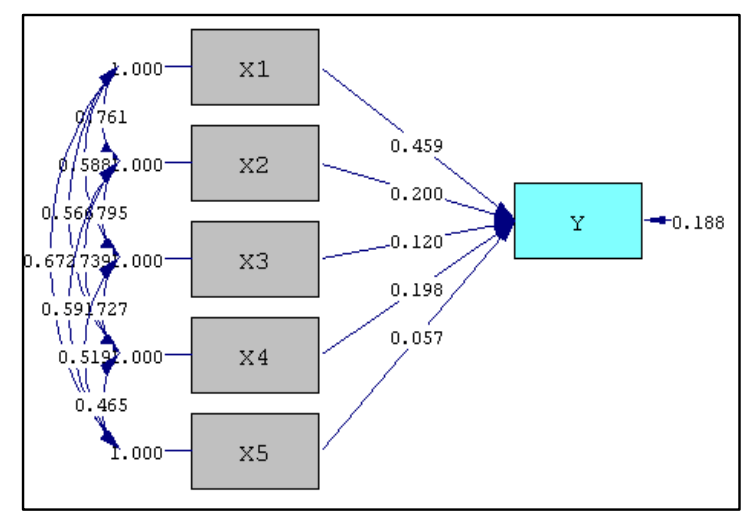

Figure 4. Path diagram of Competence (X1), Relationship (X2), Caring (X3), Trust (X4), and Sharing Information (X5) to Loyalty (Y).

By examining table 4 and Figure 5, we can get path equation (3) that is:

$$
\mathrm{Y}=0,459 \mathrm{X}_{1}+0.200 \mathrm{X}_{2}+0.120 \mathrm{X}_{3}+0,198 \mathrm{X}_{4}+0.057 \mathrm{X}_{5}+\varepsilon_{1}
$$

\section{J. The Whole Test}

The main research hypothesis is Competence (X1),
Relationship (X2), Caring (X3), Trust (X4), and Sharing Information (X5) which have simultaneous effects to Loyalty $(\mathrm{Y})$. The research hypothesis can be described in statistical hypothesis and statistical test in (4).

$$
\begin{aligned}
& \mathrm{H} 0: \rho_{y \times 1}=\rho_{y \times 2}=\rho_{y \times 3}=\rho_{y x 4}=\rho_{y \times 5}=0 \\
& \mathrm{H} 1: \text { at least there is one of } \rho_{y \times i} \neq 0, \mathrm{i}=1,2,3,4 \text { and } 5 \\
& F=\frac{(n-k-1) \sum_{i=1}^{k} \rho_{y x i} r_{y x i}}{k\left(1-\sum_{i=1}^{k} \rho_{y x i} r_{y x i}\right)}
\end{aligned}
$$

Test criterion, Reject $\mathrm{H} 0$ if $\mathrm{F}$ count $\geq \mathrm{F}$ table, Accept $\mathrm{H}_{0}$ in other hand. While $\mathrm{F}$ table is obtained from table $\mathrm{F}$ distribution, table with $\alpha=5 \%$ and degrees of freedom $\mathrm{db} 1$ is $=\mathrm{k}$ and $\mathrm{db} 2=\mathrm{n}-\mathrm{k}-1$.

TABle 5. Simultaneous Test

\begin{tabular}{|c|c|c|c|c|c|}
\hline $\begin{array}{c}\text { Alternative } \\
\text { Hypothesis }\end{array}$ & F count & $\mathrm{db}$ & $\begin{array}{c}\mathrm{F} \\
\text { table }\end{array}$ & Decision & $\begin{array}{c}\text { Conclusi } \\
\text { on }\end{array}$ \\
\hline $\begin{array}{c}\mathrm{X} 1, \mathrm{X} 2, \mathrm{X} 3, \\
\mathrm{X} 4 \text { and X5 } \\
\text { Simultaneous } \\
\text { To Y }\end{array}$ & 152,380 & $\mathrm{db}_{1}=5$ & 2,2 & $\begin{array}{c}\mathrm{H}_{0} \\
\text { rejected }\end{array}$ & $\begin{array}{c}\text { Significa } \\
\mathrm{nt}\end{array}$ \\
& & 65 & & \\
\cline { 3 - 6 } & & $\mathrm{db}_{2}=176$ & & & \\
\hline
\end{tabular}

In table 5, we are informed that test results is significant, it means simultaneous Competence (X1), Relationship (X2), Caring (X3), Trust (X4), and Sharing Information (X5) have significant effect to Loyalty (Y).

\section{K. Partial Test}

Because the test show the significant results, so to know the independent variable that have effect to $\mathrm{Y}$ we have to use partial test. To examine path coefficient partially, we have to know about the hypothesis of equity (5):

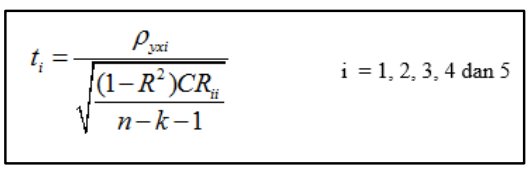

$H_{0}: \rho_{y x}={ }_{i}$, There is no real effect from independent variable $\mathrm{Xi}$ to $\mathrm{Y}$.

$H_{1}: \rho_{y x_{i}} \neq 0$, however, there is a real effect from independent variable $\mathrm{Xi}$ to $\mathrm{Y}$.

TABle 6. Result of Partial Test 


\begin{tabular}{|c|c|c|c|c|c|c|}
\hline & $\begin{array}{l}\text { Hypothes } \\
\text { is }\end{array}$ & $t$ count & db & t tablr & Decision & Conclusion \\
\hline 1 & $P_{y \times 1}=0$ & 8,227 & \multirow{5}{*}{176} & 1.974 & H0 rejected & Significant \\
\hline 2 & $\mathrm{P}_{\mathrm{yx2} 2}=0$ & 2,831 & & 1.974 & $\mathrm{H} 0$ rejected & Significant \\
\hline 3 & $P_{y \times 3}=0$ & 2,077 & & 1.974 & $\mathrm{H} 0$ rejected & Significant \\
\hline 4 & $P_{y \times 4}=0$ & 3,841 & & 1.974 & $\mathrm{H} 0$ rejected & Significant \\
\hline 5 & $P_{y x 5}=0$ & 1,255 & & 1.974 & H0 accepted & $\begin{array}{l}\text { Not } \\
\text { Significant }\end{array}$ \\
\hline
\end{tabular}

Based on table 6 we can know that tcount for each variable Competence (X1), Relationship (X2), Caring (X3), Trust (X4) are bigger than table. It means Competence (X1), Relationship (X2), Caring (X3), and Trust (X4) partially give significant effect to Loyalty (Y). However tcalc for Sharing Information (X5) is smaller than table. Thus, we can decide that Sharing Information (X5) partially does not give significant effect to loyalty (Y).

\section{CONCLUSION AND SUGGESTION}

Based on the research goal, which is to discover the factors that have effect to Customer Loyalty in Telkom e-service implementation as CRM Tools for Speedy/Indihome customer in Jakarta, research model that is conducted by Krishnamoorthy and Srinivasan [13] on telecommunication services is implemented in this study. In this research we perform data processing and hypothesis, a n d test the hypothesis based on survey results of 182 respondents who are Speedy/Indihome customers. From data calculation and analysis we can conclude that:

1. From calculation we get CRM score that is $75,01 \%$ and it is good. By knowing the variables that have effect to customer loyalty and performing appropriate improvement based on this research, Telkom e-service as CRM tools can increase customer loyalty effectively. Customer loyalty score based on this research is $70,1 \%$.

2. Based on customer appraisal, we get the path equation that is:

$$
\begin{gathered}
\mathrm{Y}=0,459 \mathrm{X}_{1}+0.200 \mathrm{X}_{2}+0.120 \mathrm{X}_{3}+0,198 \mathrm{X}_{4}+0.057 \\
\mathrm{X}_{5}+\varepsilon 1
\end{gathered}
$$

Based on the equity we can reveal that path coefficient from Competence (X1) is bigger than Relationship (X2), Caring (X3), Trust (X4), and Sharing Information (X5). It means that Competence is more decisive to loyalty than Relationship (X2), Caring (X3), Trust (X4), and Sharing Information (X5) not only directly but also indirectly. The effect of total variable Competence, Relationship, Caring, Trust, and Sharing Information to customer loyalty is 0,812 or $81,2 \%$, but the other factor of loyalty is 0,188 .

3. From the research we know that the effect of Competence (X1) to loyalty (Y) is $38,23 \%$ and this is the most decisive variable. Telkom e-service as CRM Tools has to focus to increase the competence of the management. Telkom has to standardize all Telkom e-service employees. All employees have to re-asses to standardize and make sure that they are qualified.

\section{Suggestions}

1) Suggestion for Telkom as Speedy/Indihome service provider

- The variable which has the biggest effect to loyalty (Y) is Competence (X1) and the effect score is $38,23 \%$. Remember that this variable is the biggest one, therefore this variable has to be the main priority for quality improvement. The customers assume that Telkom is a competent company in internet service provider. Thus, Telkom has to rapidly make improvement related to the competency, such as performing assessment to all employee which are related to Speedy / Indihome services. Based on the assessment results we can know the strength and weakness of each person related to services. For employees who know their weakness, Telkom has to evaluate them so they will not create problem to customers.

- Speedy/Indihome customers want the intensive relationship with Telkom. With Telkom e-service, customer relationship between customers and Telkom can be better improved. Telkom has to make sure the customers that Telkom service is in customer hand.It means that Telkom e-service can be accessed from their gadget and all Telkom services are built in. Customers also have to assured that Telkom is trusted company that will give the best internet service. To develop Trust is not easy, it requires strong commitment from Telkom top management and have to be understood to the operational levels.

2) Suggestion for next researches

- The goal of the research is to discover the factors affecting to loyalty (Y). Therefore, we have to resume the research for knowing continuity from this research after Telkom makes improvement on significant factors for loyalty.

- From this research, we are informed with the results that Competence is the most influenced factor for customer loyalty. Therefore, next researches has to be more detail to support the development related to customer loyalty.

\section{References}

[1] P. Kotler, and L. Keller,. Marketing Management, 13rd Edition. New Jersey: Pearson Prentice Hall, Inc., 2012, ISBN 9780136009986.

[2] F. Tjiptono,. Pemasaran Jasa-Prinsip, Penerapan, dan Penelitian, Edisi Pertama. Yogyakarta: Andi Offset, 2014, ISBN 9789792944174.

[3] P. Kotler, and L. Keller, Manajemen Pemasaran Jilid 1, Edisi Ketiga Belas, Jakarta: Penerbit Erlangga, Jakarta, 2009, ISBN 9789790339354.

[4] K.J. Clancy, and R.S. Shulman, Marketing Myths That Are Killing Business : The Cure for Death Wish Marketing. New Yor: McGrawHill Professional, 1994, ISBN 978-0070113619 
[5] M. Raphel, and N. Raphel, Up The Loyalty Ladder. 1st Edition. New York: Harpercollins Publishers, 1995, ISBN 9780887307867.

[6] Sugiyono, Metode Penelitian Bisnis (Pendekatan Kualitatif, Kuantitatif, dan R\&D). Bandung: Alfabeta, 2009, ISBN 9798433640.

[7] S. Jonathan, Metode Penelitian Kualitatif dan Kuantitatif. Yogyakarta: Graha Ilmu, 2006, ISBN 978-979-756-146-8.

[8] F. Augusty, Metode Penelitian Manajemen. Semarang: Badan Penerbit Universitas Diponegoro, 2006.

[9] N. K. Malhotra, Marketing Research : an Applied Orientation Fifth edition, New Jersey: Pearson/Prentice Hall, 2006, ISBN 9780132221177

[10] R. Kaplan, \& D.P. Saccuzzo, Phsycological Testing Principles, Application, and Issues. California: Brooks Cole Publishing Company, 1993, ISBN 978-0534162337

[11] H. Umar, Metode Riset Bisnis, Jakarta: Gramedia Pustaka Utama, 2008.

[12] Sekaran, Research Method for Business, Jakarta: Salemba Empat, 2006, ISBN 979-691-316-x.

[13] V. Krishnamoorthy, and R. Srinivasan, "Impact of Customer Relationship Management on Loyalty in Indian Banking Sector - An Empirical Study", International Monthly Refereed of Research ini Management and Technology, Vol II, 2013, pp.150-161. 